\title{
Isotopic events in the Early/Middle Badenian (Miocene) of the Upper Silesia Basin (Central Paratethys)
}

\author{
Małgorzata GONERA and Krzysztof BUKOWSKI
}

Gonera M. and Bukowski K. (2012) - Isotopic events in the Early/Middle Badenian (Miocene) of the Upper Silesia Basin (Central Paratethys). Geol. Quart., 56 (3): 561-568, doi: 10.7306/gq.1040

\begin{abstract}
Middle Miocene foraminifera from the Skawina Formation of the Upper Silesia Basin have been analysed. The stable oxygen and carbon isotope signatures in Globigerinoides quadrilobatus (shallow pelagic), Globigerina bulloides (deeper pelagic) and Uvigerina spp. (benthic) tests show a temporal pattern of changes in the sections studied. The foraminiferal assemblage biozones of the Badenian that were identified earlier, on the basis of taxonomic composition, correspond to changes in the foraminiferal $\delta^{18} \mathrm{O}$ and $\delta^{13} \mathrm{C}$ values. The $\mathrm{CPN7/CPN8} \mathrm{transition} \mathrm{-} \mathrm{as} \mathrm{the} \mathrm{Moravian/Wielician} \mathrm{border} \mathrm{-} \mathrm{is} \mathrm{marked} \mathrm{by} \mathrm{distinct} \mathrm{isotopic} \mathrm{events:} \mathrm{a} \delta^{18} \mathrm{O}$ increase (IIAB/IIC boundary) followed by a $\delta^{13} \mathrm{C}$ decrease (IIC/IID boundary).
\end{abstract}

Matgorzata Gonera, Institute of Nature Conservation, Polish Academy of Sciences, A. Mickiewicza 33, 31-120 Kraków, Poland, e-mail: gonera@iop.krakow.pl; Krzysztof Bukowski, Faculty of Geology, Geophysics and Environmental Protection, AGH University of Science and Technology, A. Mickiewicza 30, 30-059 Kraków, Poland, e-mail: buk@agh.edu.pl (received: April 29, 2011; accepted: July 30, 2012; first published online: August 29, 2012).

Key words: Middle Miocene, Wielician, Paratethys, foraminifera, stable isotopes.

\section{INTRODUCTION}

The composition of foraminifer assemblages shows distinct lateral and temporal taxonomic changes in the Badenian of the Carpathian Foredeep and Vienna Basin. The temporal changes have been related to characteristic, well-defined assemblage biozones with the status of biostratigraphic zones (e.g., Alexandrowicz, 1963; Łuczkowska, 1964; Cicha et al., 1975). Palaeoecological research indicated that significant modifications of the taxonomic composition and hence constitution of new assemblage biozones in the profile occurred as a result of considerable environmental changes (Szczechura, 1982; Gonera, 2001; Bicchi et al., 2003). These Badenian foraminiferal biozones of the Carpathian Foredeep have the nature of ecozones.

The aim of the research conducted presently is to check the relationships between those foraminiferal biozones and geochemical parameters of the foraminiferal tests. Our studies concerned the Skawina Formation where as many as three such foraminiferal assemblage biozones are identified in the strata prior to the Badenian evaporites (Alexandrowicz, 1963). One of the geochemical features of the mineral skeleton of foraminifera are the ratios of stable oxygen and carbon isotopes (Elderfield, 2004). Several such studies have been already performed on Badenian foraminifera (e.g., Durakiewicz et al., 1997; Gonera et al., 2000, 2003; Báldi, 2006; Hohenegger et al., 2008; Kovačova and Hudačkova, 2009; Peryt and Gedl, 2010). We present new data on $\delta^{18} \mathrm{O}$ and $\delta^{13} \mathrm{C}$ values of foraminifers occurring below the Badenian evaporites and discuss their stratigraphic implications.

\section{GEOLOGICAL SETTING}

The area studied (Upper Silesia Basin) was a part of the Carpathian Foredeep Basin during the Middle Miocene (Fig. 1). The Middle Miocene sequence of the Upper Silesia Basin is well-known owing to studies of Alexandrowicz (1963), and subsequent updates of various aspects (e.g., Barwicz-Piskorz, 1997; Gedl, 1997; Gonera, 1997, 2001; Górka, 1997; Peryt, 1997; Sadowska, 1997; Szczechura, 1997; Witkowski and Gonera, 1997). 

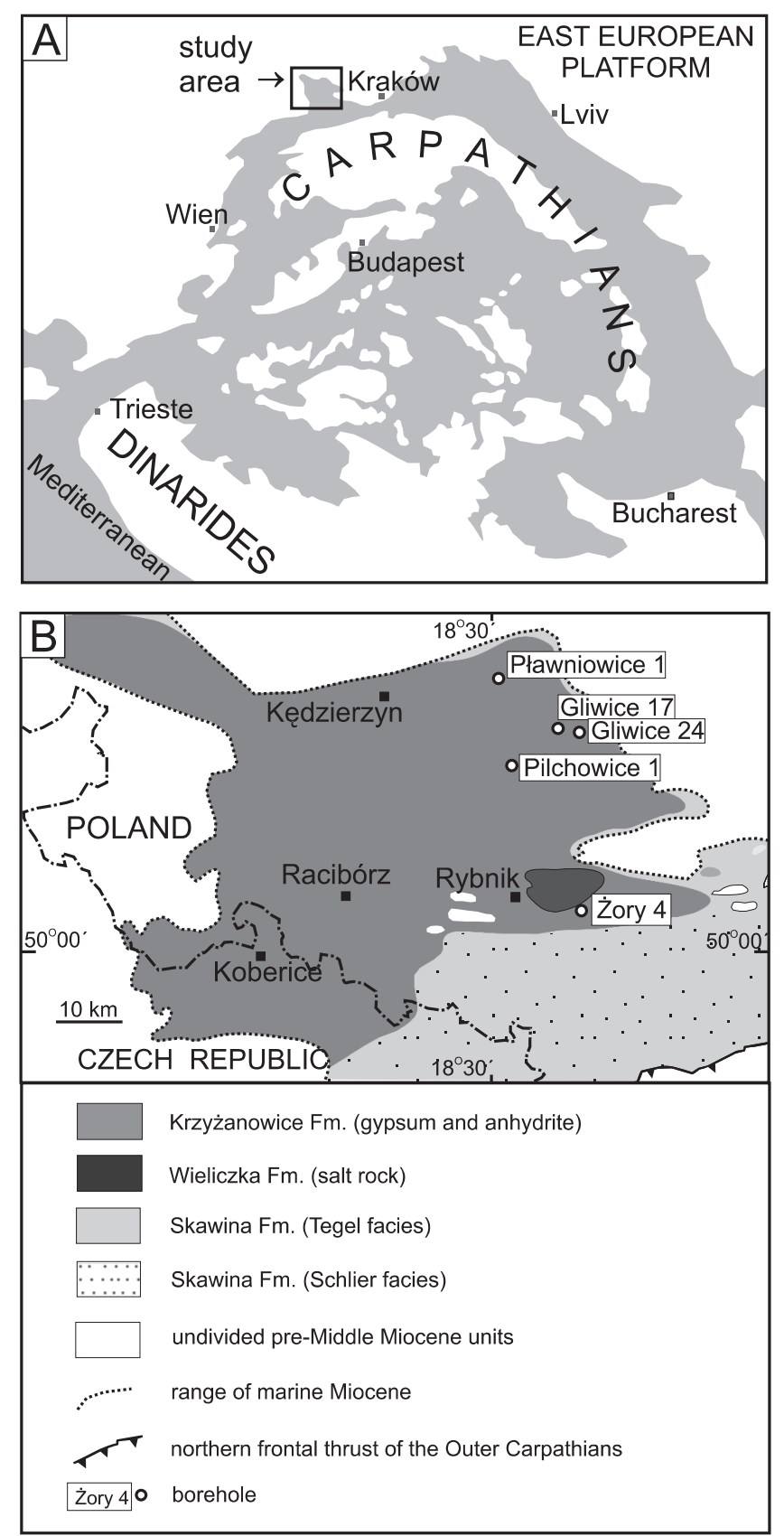

Fig. 1. Area studied

A - palaeogeographic reconstruction of the Central Paratethys (Early Badenian marine sedimentation; after Rögl, 1998); B - Upper Silesian Basin and the boreholes investigated

Four lithostratigraphic units have been proposed for those strata: the Skawina Fm., Krzyżanowice Fm. and Wieliczka Fm. (evaporites), and the Gliwice Fm. (Alexandrowicz et al., 1982). The Skawina Fm. consists of grey marly clays (Tegel) primarily, partially with sand or silty gravel admixtures and intercalations of shelly and organodetrital limstones or marls (Alexandrowicz, 1963, 1997). Evaporites consist of gypsum (e.g., Peryt et al., 1997) and, only in the Rybnik and Żory area, halite with claystone and anhydrite intercalations (Garlicki, 1979).

\section{MATERIALS AND METHODS}

We have studied the Skawina Fm. deposits in five boreholes located along a $\mathrm{N}-\mathrm{S}$ transect of the Silesian Basin (Fig. 1). The material for this study (samples and lithological descriptions of boreholes) came from the collection and unpublished materials of Prof. S.W. Alexandrowicz. A complete set of foraminiferal biozones characteristic of the Badenian section below the evaporites was found in the deposits studied (Table 1; Gonera, 2001).

In the Pławniowice 1, Pilchowice 1 and Żory 4 boreholes, the Skawina Formation lies on the sands and silts with Cepaea and Congeria shells, plant fragments and pebbles of older rocks (Early Miocene Kłodnica Formation). The productive Carboniferous rocks (clayey shale with coal intercalations) comprise the basement of the Skawina Formation in the Gliwice 17 and Gliwice 24 boreholes. The Skawina Formation is developed as non-stratified marly clays (typical Tegel facies) in the Pilchowice 1 and Żory 4 profiles. In the other boreholes the deposits have some admixture of sand (Schlier facies) or are intercalated with silty gravel, rhodolith debris and/or sandstones (Fig. 2). In all the profiles studied, the Skawina Fm. is overlain by Badenian evaporites, developed in sulphate facies (silty shales with gypsum and/or anhydrite).

We have analysed three foraminifer taxa constantly present in the deposits: Uvigerina spp., Globigerina bulloides d'Orbigny, 1826 and Globigerinoides quadrilobatus d'Orbigny, 1846. Such a choice allowed us to determine the isotopic composition of tests of organisms that lived on the sea floor (Uvigerina) and in near-surface waters (Globigerina and Globigerinoides), and to analyse the Skawina Formation along a the N-S transect of the sedimentary basin.

Uvigerina in the IIAB biozone (Alexandrowicz, 1963) was mainly represented by U. semiornata d'Orbigny, 1846 and the less common U. macrocarinata Papp and Turnovsky, 1953 (Fig. 3). In the IIC biozone, the $U$. semiornata specimens still dominated and were accompanied by $U$. orbignyana Czjzek, 1847. Those two taxa were present in the IID biozone, although in reverse proportions: $U$. orbignyana dominated, while $U$. semiornata were scarce. This set of uvigerinas was sampled for isotope studies. Globigerina bulloides and Globigerinoides quadrilobatus are common in the Skawina Beds, except in the top of the profile (IID) where the latter is scarce (Gonera, 1997, 2001). These foraminifera were picked from the size fraction larger than $125 \mu \mathrm{m}$. The numbers of specimens were selected in the quantities required to obtain the $2-3 \mathrm{mg}$ necessary to analyse the $\mathrm{CaCO}_{3}$ aliquot. ${ }^{18} \mathrm{O} /{ }^{16} \mathrm{O}$ and ${ }^{13} \mathrm{C} /{ }^{12} \mathrm{C}$ isotope ratios analysis was carried out for 110 aliquots collected from 58 rock samples (Table 2).

The determination of the $\delta^{18} \mathrm{O}$ and $\delta^{13} \mathrm{C}$ was carried out in the GeoZentrum Nordbayern Laboratory of the Friedrich-Alexander-Universität in Erlagen-Nürnberg, Germany. Carbonate powders were reacted with $100 \%$ phosphoric acid at $75^{\circ} \mathrm{C}$ using a Kiel III carbonate preparation line connected online to a ThermoFinnigan 252 mass spectrometer. All values are reported in permil relative to V-PDB by assigning a $\delta^{13} \mathrm{C}$ value of $+1.95 \%$ and a $\delta^{18} \mathrm{O}$ value of $-2.20 \%$ to NBS19. Reproducibility was checked by replicate analyses of laboratory standards and is better than $\pm 0.01-0.03 \%$. 
Position of the Skawina Formation (shaded area) within the Central Paratethys stratigraphy

\begin{tabular}{|c|c|c|c|c|c|}
\hline \multirow{2}{*}{\multicolumn{2}{|c|}{ Chronostratigraphy }} & \multicolumn{4}{|c|}{ Concepts of foraminiferal biostratigraphy } \\
\hline & & \multicolumn{3}{|c|}{$\begin{array}{c}\text { Cicha et al. (1975); Papp et al. (1978); } \\
\text { Rögl and Steininger (1984) }\end{array}$} & \multirow{2}{*}{$\begin{array}{c}\text { Alexandrowicz }(1963,1965) \\
\operatorname{III} \beta \\
\end{array}$} \\
\hline \multirow{7}{*}{ 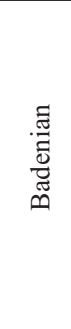 } & \multirow[b]{2}{*}{ Kosovian } & \multirow[b]{2}{*}{ CPN9 } & \multirow[b]{2}{*}{ Velapertina Zone } & Rotalia Zone & \\
\hline & & & & $\begin{array}{l}\text { Bulimina-Bolivina } \\
\text { Zone }\end{array}$ & IIIB \\
\hline & \multirow{4}{*}{ Wielician } & \multirow{4}{*}{ CPN8 } & \multirow{4}{*}{$\begin{array}{l}\text { Globigerina druryi- } \\
\text { G. decoraperta Zone }\end{array}$} & \multirow{4}{*}{$\begin{array}{l}\text { zone with } \\
\text { agglutinated } \\
\text { foraminifera }\end{array}$} & IIIA, III $\alpha$ \\
\hline & & & & & evaporite deposits \\
\hline & & & & & IID, II $\delta$ \\
\hline & & & & & $\mathrm{IIC}, \mathrm{II} \beta, \mathrm{II} \gamma$ \\
\hline & Moravian & CPN7 & Orbulina suturalis Zone & Lagenidae Zone & IIAB \\
\hline
\end{tabular}

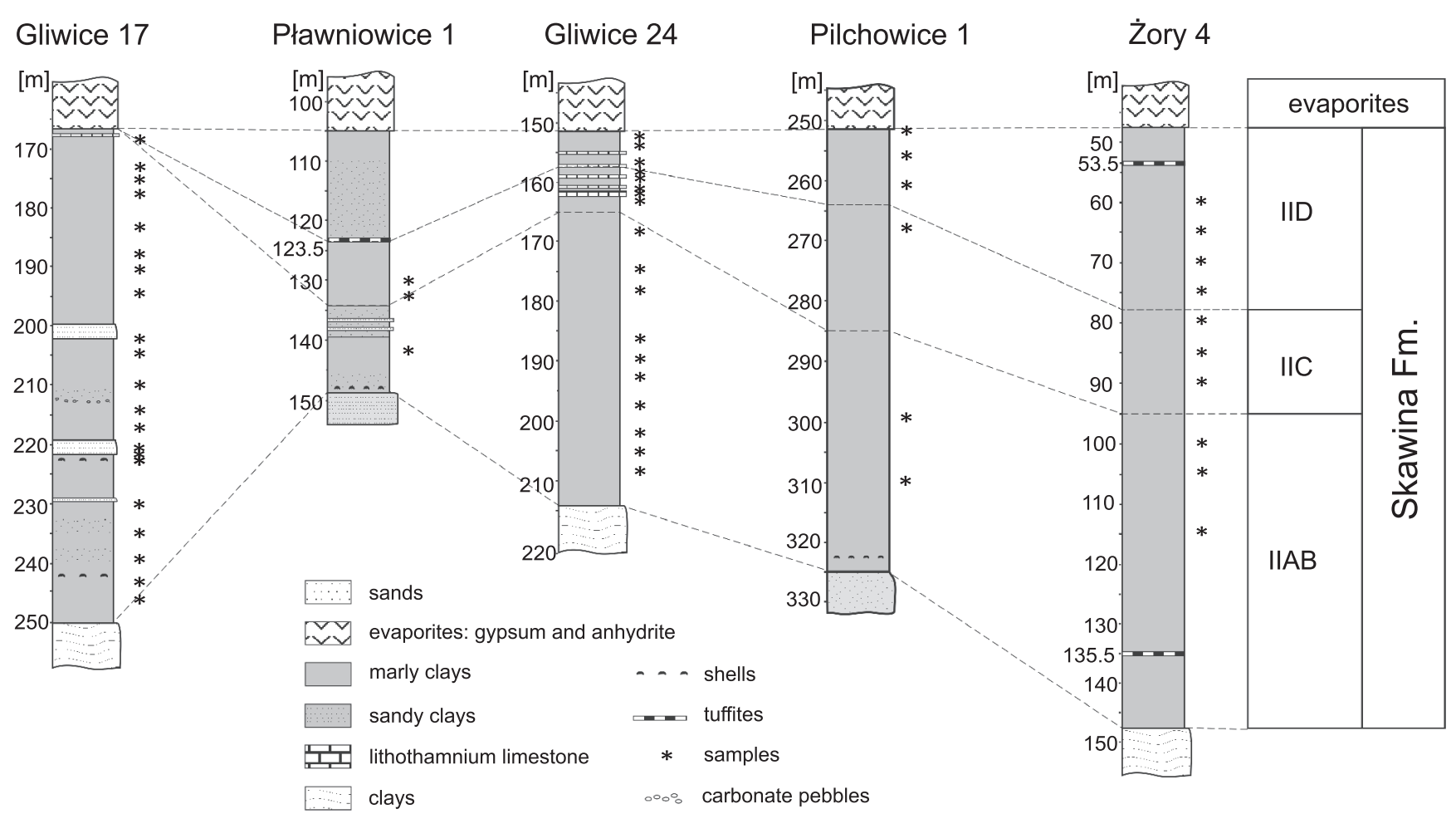

Fig. 2. Schematic lithological columns of the boreholes studied

\section{RESULTS}

The results of analyses are given in Table 2. Despite fluctuations, overall trends can be discerned regardless of the differences in absolute values for particular taxa in geographically separated boreholes (compare e.g., Uvigerina in the Pławniowice 1 and Żory 4 profiles on Table 2). Thresholds in the $\delta^{18} \mathrm{O}$ and $\delta^{13} \mathrm{C}$ values at the biozonal boundaries are distinct (Table 3 ). The results have been grouped within the biozones (Fig. 3), and the $\delta^{18} \mathrm{O}$ and $\delta^{13} \mathrm{C}$ relationships are specified in Figure 4 . The average values within the particular biozones show differences, and general patterns in the stratigraphic column may be traced.

The greatest $\delta^{18} \mathrm{O}$ change occurs on the IIAB/IIC boundary. The average $\delta^{18} \mathrm{O}$ value increases from $+1.3 \%$ (IIAB) to $+2.1 \%$ (IIC) and $+2.5 \%$ (IID) in Uvigerina. In Globigerina bulloides the $\delta^{18} \mathrm{O}$ value increases from $-0.1 \%$ (IIAB) to $+1.3 \%$ (IIC) and $+1.9 \%$ (IID), while in G. quadrilobatus the average $\delta^{18} \mathrm{O}$ value decreases from $-1.1 \%$ (IIAB) to $-1.5 \%$ (IIC).

The most noticeable $\delta^{13} \mathrm{C}$ change occurs at the IIC/IID boundary. The $\delta^{13} \mathrm{C}$ values in Uvigerina $(0 \%$ in IIAB and 


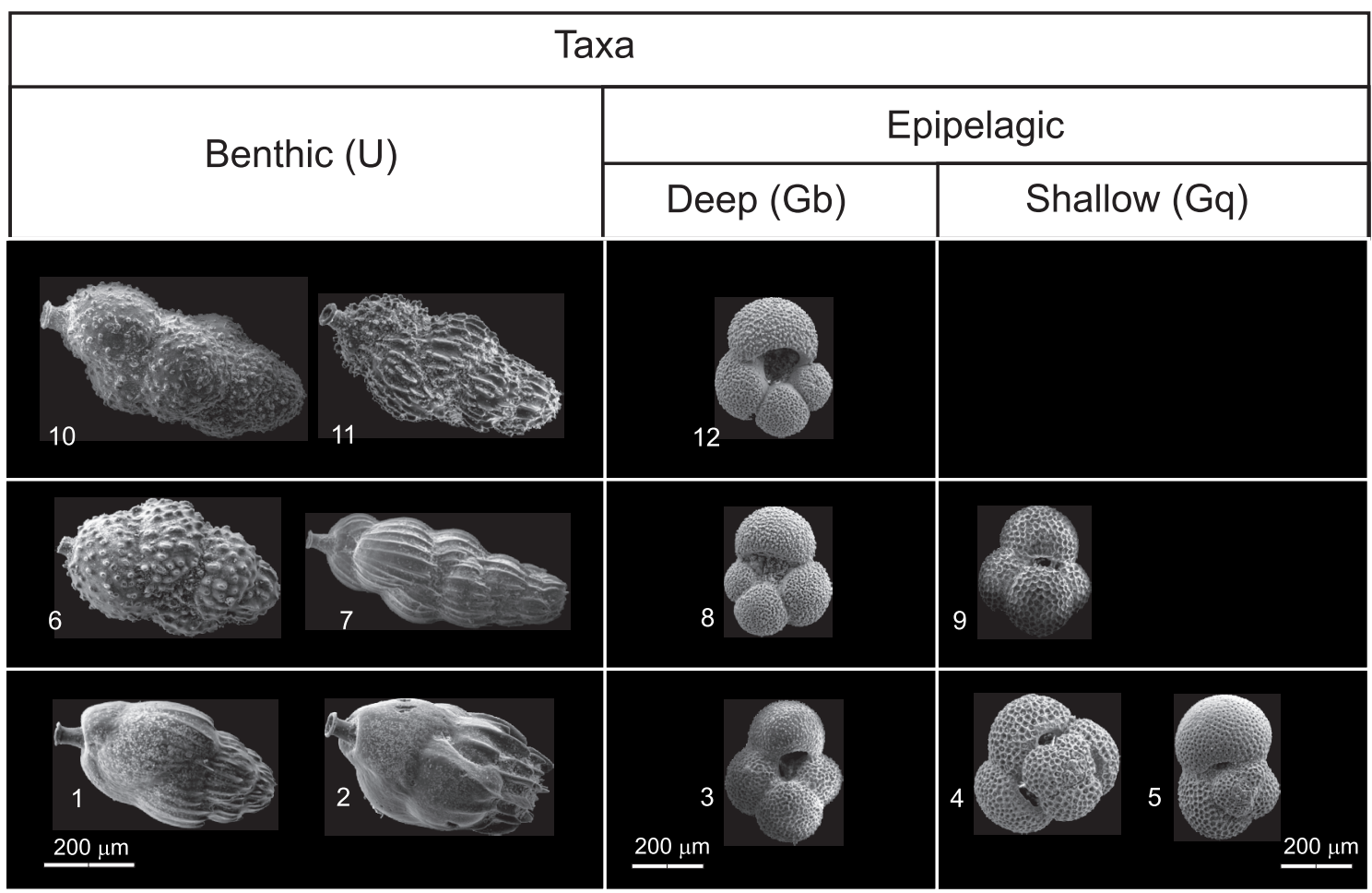

Fig. 3. SEM pictures of the taxa studied

U - Uvigerina spp., Gb - Globigerina bulloides, Gq-Globigerinoides quadrilobatus s.1.; IIAB biozone: 1 - Gliwice 24 (205.0 m), 2 , 5 - Pilchowice 1 (310.0 m), 3, 4 - Gliwice 24 (178.0 m); IIC biozone: 6 - Pławniowice 1 (130.0 m), 7 - Gliwice 24 (161.0 m), 8 Pilchowice 1 (268.0 m), 9 - Pławniowice 1 (130.0 m); IID biozone: 10 - Pilchowice 1 (261.0 m), 11 - Gliwice 24 (152.0 m), 12 Gliwice $24(157.0 \mathrm{~m})$

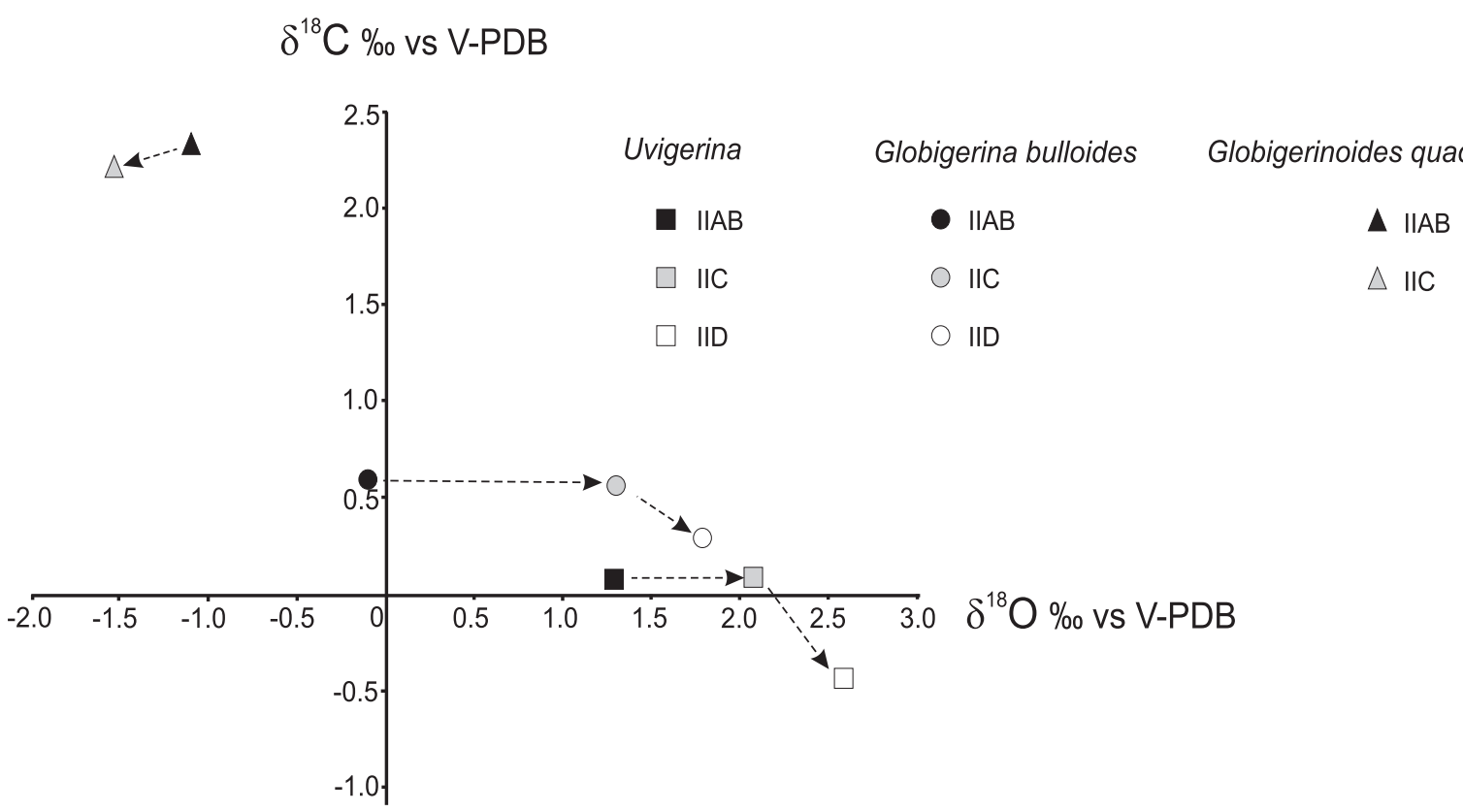

Fig. 4. Plot of average foraminiferal $\delta^{18} \mathrm{O}$ and $\delta^{13} \mathrm{C}$ values of the Skawina Formation 
Stable isotope results of oxygen $\left(\delta^{18} \mathrm{O}\right)$ and carbon $\left(\delta^{13} \mathrm{C}\right)$ of the foraminifera tests

\begin{tabular}{|c|c|c|c|c|c|c|c|c|}
\hline \multirow[t]{2}{*}{ Borehole } & \multirow[t]{2}{*}{ Biozone } & \multirow{2}{*}{$\begin{array}{c}\text { Depth } \\
{[\mathrm{m}]}\end{array}$} & \multicolumn{3}{|c|}{$\begin{array}{c}\delta^{18} \mathrm{O} \\
{[\% \circ \mathrm{V}-\mathrm{PDB}]}\end{array}$} & \multicolumn{3}{|c|}{$\begin{array}{c}\delta^{13} \mathrm{C} \\
{[\% \circ \mathrm{V}-\mathrm{PDB}]}\end{array}$} \\
\hline & & & $\mathrm{U}$ & $\mathrm{Gb}$ & $\mathrm{Gq}$ & $\mathrm{U}$ & $\mathrm{Gb}$ & $\mathrm{Gq}$ \\
\hline \multirow{3}{*}{ Pławniowice 1} & \multirow{2}{*}{ IIC } & 130.0 & 1.37 & -0.73 & -1.59 & 0.32 & 0.46 & 2.39 \\
\hline & & 133.0 & 1.32 & 0.18 & -1.38 & 0.04 & 0.45 & 2.21 \\
\hline & IIAB & 142.0 & 1.16 & 0.76 & -1.24 & 0.18 & 1.55 & 2.69 \\
\hline \multirow{21}{*}{ Gliwice 17} & \multirow{21}{*}{ IIAB } & 168.8 & 1.71 & & & 0.2 & & \\
\hline & & 173.0 & 2.00 & & & 0.08 & & \\
\hline & & 175.2 & 1.49 & -0.43 & & 0.39 & 0.74 & \\
\hline & & 177.6 & & -0.69 & & & 0.13 & \\
\hline & & 183.0 & 1.82 & 0.83 & & 0.36 & 1.63 & \\
\hline & & 187.5 & 1.45 & 0.4 & & 0.04 & 0.45 & \\
\hline & & 190.3 & 1.98 & 1.09 & & 0.03 & 1.02 & \\
\hline & & 194.5 & 1.18 & 0.49 & & -0.22 & 0.85 & \\
\hline & & 202.5 & 1.45 & 0.33 & & 0.03 & 0.75 & \\
\hline & & 204.8 & 1.3 & -0.64 & & -0.04 & 0.72 & \\
\hline & & 210.0 & 0.84 & & & 0.16 & & \\
\hline & & 214.5 & 0.89 & & & 0.15 & & \\
\hline & & 217.0 & 0.98 & -1.00 & & 0.05 & 0.84 & \\
\hline & & 220.0 & 0.85 & & & 0.59 & & \\
\hline & & 222.3 & 0.85 & & & -0.35 & & \\
\hline & & 225.5 & 0.74 & -0.82 & & 0.05 & 0.64 & \\
\hline & & 230.0 & 0.94 & -0.78 & & -0.06 & 0.2 & \\
\hline & & 235.0 & 0.75 & -0.34 & & -0.04 & 0.31 & \\
\hline & & 239.0 & 0.81 & -0.16 & & 0.92 & 0.73 & \\
\hline & & 243.5 & 0.81 & & & 0.25 & & \\
\hline & & 246.3 & 1.33 & & & -0.14 & & \\
\hline \multirow{18}{*}{ Gliwice 24} & \multirow{3}{*}{ IID } & 152.0 & 2.66 & 1.94 & & -0.28 & 0.33 & \\
\hline & & 153.6 & 2.28 & 1.57 & & -0.39 & 0.43 & \\
\hline & & 157.0 & 2.52 & 1.95 & & -0.01 & 1.00 & \\
\hline & \multirow{4}{*}{ IIC } & 158.0 & 2.41 & 1.67 & & 0.07 & 0.47 & \\
\hline & & 159.0 & 2.43 & 1.76 & & 0.1 & 0.05 & \\
\hline & & 161.0 & 2.5 & 2.17 & & -0.03 & 0.38 & \\
\hline & & 162.0 & 0.96 & -0.22 & -1.58 & 0.09 & 0.54 & 1.98 \\
\hline & \multirow{11}{*}{ IIAB } & 163.0 & 1.71 & 1.39 & -1.26 & 0.09 & 0.57 & 2.3 \\
\hline & & 168,0 & 1.38 & -0.28 & -0.56 & -0.15 & 0.26 & 1.61 \\
\hline & & 174.5 & 1.75 & 0.13 & -1.02 & -0.06 & 0.14 & 2.14 \\
\hline & & 178.0 & 1.2 & -1.1 & -1.71 & 0.03 & 0.6 & 2.62 \\
\hline & & 186.4 & 1.35 & & -1.25 & 0.04 & & 2.61 \\
\hline & & 189.2 & 1.66 & 0.23 & & -0.22 & 0.2 & \\
\hline & & 192.2 & 1.35 & 0.61 & & -0.13 & 0.56 & \\
\hline & & 197.6 & 1.19 & -0.18 & & 0.16 & 0.59 & \\
\hline & & 202.0 & 1.22 & -0.77 & & -0.08 & 0.27 & \\
\hline & & 205.0 & 0.69 & -0.8 & -1.15 & -0.09 & 0.15 & 2.16 \\
\hline & & 208.0 & 0.83 & -0.41 & & -0.34 & 0.18 & \\
\hline \multirow{6}{*}{ Pilchowice 1} & \multirow{3}{*}{ IID } & 252.0 & 1.91 & & & -1.35 & & \\
\hline & & 256.0 & 2.66 & 2.09 & & -0.28 & 0.07 & \\
\hline & & 261.0 & 2.73 & 1.73 & & -0.62 & 0.02 & \\
\hline & IIC & 268.0 & & 1.53 & & & 0.37 & \\
\hline & \multirow{2}{*}{ IIAB } & 300.0 & 1.63 & & & -0.14 & & \\
\hline & & 310.0 & 1.03 & -0.38 & -1.57 & -0.2 & 0.3 & 1.95 \\
\hline
\end{tabular}


Tab. 2 cont.

\begin{tabular}{|c|c|c|c|c|c|c|c|c|}
\hline \multirow[t]{2}{*}{ Borehole } & \multirow[t]{2}{*}{ Biozone } & \multirow{2}{*}{$\begin{array}{l}\text { Depth } \\
\text { [m] }\end{array}$} & \multicolumn{3}{|c|}{$\begin{array}{c}\delta^{18} \mathrm{O} \\
{\left[\%{ }^{\circ} \mathrm{V}-\mathrm{PDB}\right]}\end{array}$} & \multicolumn{3}{|c|}{$\begin{array}{c}\delta^{13} \mathrm{C} \\
{[\% \circ \mathrm{V}-\mathrm{PDB}]}\end{array}$} \\
\hline & & & $\mathrm{U}$ & $\mathrm{Gb}$ & $\mathrm{Gq}$ & $\mathrm{U}$ & $\mathrm{Gb}$ & $\mathrm{Gq}$ \\
\hline \multirow{10}{*}{ Żory 4} & \multirow{4}{*}{ IID } & 60.0 & 2.57 & & & -0.78 & & \\
\hline & & 65.0 & 2.6 & 1.97 & & -0.52 & -0.09 & \\
\hline & & 70.0 & 2.55 & & & -0.38 & & \\
\hline & & 75.0 & 2.9 & & & 0.37 & & \\
\hline & \multirow{3}{*}{ IIC } & 80.0 & 2.63 & 2.1 & & 0.01 & 0.84 & \\
\hline & & 85.0 & 2.82 & 2.05 & & -0.02 & 0.61 & \\
\hline & & 90.0 & & 2.3 & & & 1.1 & \\
\hline & \multirow{3}{*}{ IIAB } & 100.0 & 1.96 & & -1.03 & -0.09 & & 2.33 \\
\hline & & 105.0 & & & -1.16 & & & 2.68 \\
\hline & & 115.0 & 2.07 & 0.45 & -0.13 & 0.09 & 0.85 & 2.41 \\
\hline
\end{tabular}

For explanations see Figure 3

$+0.1 \%$ in IIC) decrease to $-0.4 \%$ in IID. In G. bulloides, the respective values are $+0.6 \%$ (IIAB) and $+0.5 \%$ (IIC), and decrease to $+0.3 \%$ (IID). For G. quadrilobatus, we obtained data only for the lower part of the profile, i.e. IIAB and IIC biozones, where the $\delta^{13} \mathrm{C}$ values reach +2.4 and $+2.2 \%$, respectively.

The strongest change in $\delta^{18} \mathrm{O}$ content of the deeper pelagic foraminifers ( $G$. bulloides) takes place at the IIAB/IIC border where there is an increase by $1.4 \%$ (from -0.1 to $+1.3 \%$ ). A significant change in $\delta^{18} \mathrm{O}$ occurs also at this boundary in the benthic foraminifers (Uvigerina); from +1.3 to $+2 \%$. In the younger deposits (IID biozone), a further increase in $\delta^{18} \mathrm{O}$ is noted: of $0.6 \%$ for Globigerina bulloides and $0.5 \%$ for Uvigerina. The difference between those benthic and pelagic foraminifers $\left(\Delta \delta^{18} \mathrm{O}\right)$ underwent continuous reduction during this interval of the Badenian: from $1.4 \%$ in IIAB to $0.8 \%$ in IIC and $0.7 \%$ in IID.

The $\delta^{13} \mathrm{C}$ changes are not as prominent as in the case of the $\delta^{18} \mathrm{O}$ values. At the IIAB/IIC boundary, the average $\delta^{13} \mathrm{C}$ value decreases by $0.1 \%$ in $G$. bulloides (from +0.6 to $+0.5 \%$ ) and increases by $0 \%$ in Uvigerina (from +0 to $+0.1 \%$ ). Noticeable $\delta^{13} \mathrm{C}$ change occurs between the IIC and IID biozones. At this boundary there is a distinctive drop in $\delta^{13} \mathrm{C}$ values of both planktonic and benthic foraminifers. The average $\delta^{13} \mathrm{C}$ values decrease by $0.5 \%$ in Uvigerina tests (from +0.1 to $-0.4 \%$ ) and by $0.2 \%$ in Globigerina bulloides (from +0.5 to $+0.3 \%$ ).

\section{IMPLICATIONS}

The subdivision of the Badenian Stage into three parts is based on distinct faunal turnovers registered in marine deposits across the Central Paratethys (Table 1). In this chronostratigraphic concept, the Moravian and Kosovian are defined as time spans of normal marine sedimentation (Brestenská, 1978a), and thus they are easily defined by marine planktonic index taxa (Orbulina suturalis and Velapertina indigena respectively).

By contrast, the Wielician hallmark is of evaporites - the deposits of a salinity crisis developed in the Central Paratethys (Peryt, 2006; de Leeuw et al., 2010, with references therein).

Foraminiferal isotopic composition of the Skawina Formation biozones

\begin{tabular}{|l|c|c|c|}
\hline \multirow{2}{*}{ Biozone } & \multirow{2}{*}{$\begin{array}{c}\text { Number } \\
\text { of data }\end{array}$} & $\begin{array}{c}\delta^{18} \mathrm{O} \\
\text { Average (standard deviation } \\
\text { in brackets) and median }\end{array}$ & $\begin{array}{c}\text { Average (standard deviation } \\
\text { in brackets) and median }\end{array}$ \\
\hline \multirow{3}{*}{ IID } & 6 & Gb: $1.88(0.19) ; 1.95$ & Gb: $0.29(0.40) ; 0.20$ \\
\hline \multirow{4}{*}{ IIC } & 10 & U: $2.54(0.27) ; 2.59$ & U: $-0.42(0.46) ;-0.39$ \\
\cline { 2 - 4 } & 3 & Gq: $-1.52(0.12) ;-1.58$ & Gq: $2.19(0.21) ; 2.21$ \\
\hline \multirow{3}{*}{ IIAB } & 10 & Gb: $1.28(1.11) ; 1.72$ & Gb: $0.53(0.28) ; 0.47$ \\
\cline { 2 - 4 } & 8 & U: $2.06(0.72) ; 2.42$ & U: $0.07(0.11) ; 0.06$ \\
\cline { 2 - 4 } & 11 & Gq: $-1.10(0.44) ;-1.16$ & Gq: $2.31(0.34) ; 2.33$ \\
\cline { 2 - 4 } & 26 & Gb: $-0.10(0.71) ;-0.23$ & Gb: $0.59(0.39) ; 0.58$ \\
\hline
\end{tabular}


These deposits occur across most of Carpathian Foredeep. Globigerina druryi and/or G. decoraperta have been accepted as the index taxa of the Wielician substage (Cicha et al., 1975). Nevertheless, other foraminiferal indicators are often applied in stratigraphic practice. The Agglutinated Foraminifera Zone, also known as the Uvigerina costai Zone (Łuczkowska, 1964) or the Pseudotriplasia Zone (Papp et al., 1978) as well as the onset of the Globigerina bulloides acme (Gonera, 1997) are among commonly used Wielician indicators. The Moravian/Wielician biotic change is well-recognized in, for example, the K-5 and ŽI-2 boreholes (Danube Lowland Basin) representative of one of the Badenian faciostratotypes (Brestenská, 1978b).

Foraminiferal palaeoecology shows a climatically driven environmental change at the Moravian/Wielician boundary (also known as CPN7/8) correlated with the Mi3 event (Gonera, 2001; Gonera et al., 2003; Harzhauser et al., 2011) i.e. the change from the Middle Miocene Climate Optimum to the Middle Miocene Climate Transition. Our isotopic analyses provide chemostratigraphic evidence of the lower boundary of the Wielician. The results of the oxygen and carbon stable isotopes indicate that this stratigraphic boundary is characterized by strong, environmentally controlled, isotopic change. Due to the air temperature decrease (the resulted in foraminiferal $\delta^{18} \mathrm{O}$ increase) sea surface productivity was enhanced $\left(\delta^{13} \mathrm{C}\right.$ decrease, Globigerina bulloides acme), in the environmental change at the beginning of the Wielician.

\section{CONCLUSIONS}

1. The stable oxygen and carbon isotope ratios in the tests of G. quadrilobatus (shallow pelagic), G. bulloides (deeper pe- lagic) and Uvigerina (benthic) show temporal changes in the Skawina Formation prior to the Badenian evaporite deposition.

2. The foraminiferal assemblage biozones of the Skawina Fm. identified in the 1960s are distinctive units in terms of the $\delta^{18} \mathrm{O}$ and $\delta^{13} \mathrm{C}$ ratios of their foraminiferal tests. Changes in the isotopic composition coincide with biozonal boundaries: the IIAB/IIC boundary coincides with a strong increase in $\delta^{18} \mathrm{O}$, while the IIC/IID boundary coincides with notable decrease in $\delta^{13} \mathrm{C}$.

3. The foraminiferal $\mathrm{C}$ and $\mathrm{O}$ stable isotope events detected below the Badenian evaporite can be applied as stratigraphic markers in correlation across the Carpathian Foredeep.

4. The general $\mathrm{C}$ and $\mathrm{O}$ isotopic trends in foraminifers of the Skawina Formation are not affected by the presence of sand and/or rhodolith debris occurring in various parts of the profiles (most frequently in the IIC biozone). Such shallow-water facies are apparently not in situ and represent slump deposits in the Tegel sedimentation area.

5. The lower boundary of the Wielician substage lies at change from the Middle Miocene Climate Optimum to the Middle Miocene Climate Transition, at the point where a normal marine environment (Orbulina suturalis Zone) starts to transform into salinity crisis environments of the Central Paratethys. In the Polish Carpathian Foredeep this turning point is located within the Skawina Formation.

Acknowledgements. The material for these studies was kindly made available by Prof. S.W. Alexandrowicz. We are grateful for the useful comments of Dr. M. Jasionowski, Prof. S. Filipescu and Prof. T.M. Peryt. The Polish Ministry of Sciences and Higher Education financed the research under Project AGH No. 11.11.140.562.

\section{REFERENCES}

ALEXANDROWICZ S.W. (1963) - Stratigraphy of the Miocene deposits in the Upper Silesian Basin (in Polish with English summary). Prace Inst. Geol., 39.

ALEXANDROWICZ S.W. (1965) - L'évolution de l'avant-fosse des Carpathes et la stratigraphie du Miocène de la Pologne meridionale. Carpatho-Balkan Geological Association, VII Congress Sofia, Reports, II, 1: 189-193.

ALEXANDROWICZ S.W. (1997) - Lithostratigraphy of the Miocene deposits in the Gliwice area (Upper Silesia, Poland). Bull. Pol. Acad. Sc. Earth Sc., 45 (2-4): 167-179.

ALEXANDROWICZ S.W., GARLICKI A. and RUTKOWSKI J. (1982) Podstawowe jednostki litostratygraficzne miocenu zapadliska przedkarpackiego. Kwart. Geol., 26 (2): 470-471.

BÁLDI K. (2006) - Paleoceanography and climate of the Badenian (Middle Miocene, 16.4-13.0 Ma) in the Central Paratethys based on foraminifera and stable isotope $\left(\delta^{18} \mathrm{O}\right.$ and $\left.\delta^{13} \mathrm{C}\right)$ evidence. Int. J. Earth Sc. (Geol. Rd.), 95: 119-142.

BARWICZ-PISKORZ W. (1997) - Badenian (Miocene) radiolaria from the Gliwice area (Upper Silesia, Poland). Bull. Pol. Acad. Sc., Earth Sc., 45 (2-4): 87-95.

BICCHI E., FERRERO E. and GONERA M. (2003) - Paleoclimatic interpretation based on Middle Miocene planktonic Foraminifera: the
Silesia Basin (Paratethys) and Monferrato (Tethys) record. Palaeogeogr. Palaeoclimatol. Palaeoecol., 196: 265-303.

BRESTENSKÁ E., ed. (1978a) - Chronostratigraphie und Neostratotypen: Miozän der Zentralen Paratethys. Bd. VI. M4 Badenian (Moravien, Wielicien, Kosovien). VEDA SAV, Bratislava.

BRESTENSKÁ E. (1978b) - Faziostratotypen des Badenien. In: Chronostratigraphie und Neostratotypen: Miozän der Zentralen Paratethys (ed. E. Brestenská): 175-188. Bd. VI. M4 Badenian (Moravien, Wielicien, Kosovien). VEDA SAV, Bratislava.

CICHA I., ČTYROKÁ J., JIŘIČEK R. and ZAPLETALOVÁ I. (1975) Principal biozones of the Late Tertiary in East Alps and West Carpathians. In: Biozonal Division of the Upper Tertiary Basins of the Eastern Alps and West Carpathians (ed. I. Cicha ): 19-34. IUGS Proccedings of the VI. Congress, Bratislava.

De LEEUW A., BUKOWSKI K., KRIJGSMAN W. and KUIPER K.F. (2010) - The age of the Badenian Salinity Crisis; impact of Miocene climate variability on the Circum-Mediterranean region. Geology, 38: 715-718.

DURAKIEWICZ T., GONERA M. and PERYT T.M. (1997) - Oxygen and carbon isotopic changes in the Middle Miocene (Badenian) Foraminifera of the Gliwice area (SW Poland). Bull. Pol. Acad. Sc., Earth Sc., 45 (2-4): 145-156. 
ELDERFIELD H., ed. (2004) - The oceans and marine geochemistry. In: Treatise on Geochemistry (eds. K.K. Holland and H.D. Turekian). Elsevier Ltd, 6.

GARLICKI A. (1979) - Sedimentation of Miocene salts in Poland (in Polish with English summary). Prace Geol. Komis. Nauk Geol. PAN Krak., 119.

GEDL P. (1997) - Palynofacies of the Miocene deposits in the Gliwice area (Upper Silesia, Poland). Bull. Pol. Acad. Sc., Earth Sc., 45 (2-4): 191-201.

GONERA M. (1997) - Miocene foraminiferal assemblages in the Gliwice area (Upper Silesia, Poland). Bull. Pol. Acad. Sc., Earth Sc., 45 (2-4): 97-105.

GONERA M. (2001) - Foraminiferida and paleoenvironment of the Badenian formations (Middle Miocene) in the Upper Silesia (Poland) (in Polish with English summary). Studia Naturae, 48: 1-211.

GONERA M., PERYT T.M. and DURAKIEWICZ T. (2000) Biostratigraphical and paleoenvironmental implications of isotopic studies $\left({ }^{18} \mathrm{O},{ }^{13} \mathrm{C}\right)$ of the middle Miocene (Badenian) foraminifers in the Central Paratethys. Terra Nova, 12: 231-238.

GONERA M., PERYT T.M. and DURAKIEWICZ T. (2003) - Coiling direction in Globigerina bulloides of Middle Miocene age. J. Micropaleont., 22: 141-146.

GÓRKA H. (1997) - Holothurian sclerites from the Miocene deposits of the Gliwice area (Upper Silesia, Poland). Bull. Pol. Acad. Sc., Earth Sc., 45: 107-118.

HARZHAUSER M., PILLER W. E., MÜLLEGGER S., GRUNERT P. and MICHEELS A. (2011) - Changing seasonality patterns in Central Europe from Miocene Climate Optimum to Miocene Climate Transition deduced from the Crassostrea isotope archive. Glob. Planet. Change, 76: 155-169

HOHENEGGER J., ANDERSEN N., BÁLDI K., ĆORIĆ S., PERVESLER P., RUPP CH. and WARGERICH M. (2008) - Paleoenvironment of the Early Badenian (Middle Miocene) in the southern Vienna Basin (Austria) - multivariate analysis of the Baden-Sooss section. Geol. Carpath., 59: 461-487.

KOVAČOVA P. and HUDAČKOVÁ N. (2009) - Late Badenian foraminifers from the Vienna Basin (Central Paratethys): stable isotope study and paleoecological implications. Geol. Carpath., 60 (1): $59-70$.
ŁUCZKOWSKA E. (1964) - The micropaleontological stratigraphy of the Miocene in the region of Tarnobrzeg-Chmielnik (in Polish with English summary). Prace Geol. Komis. Nauk Geol. PAN Krak., 20.

PAPP A., CICHA I. and SENEŠ J. (1978) - Gliederung des Badenian, Faunenzonen und Unterstufen. In: Chronostratigraphie und Neostratotypen: Miozän der Zentralen Paratethys (ed. E. Brestenská): 49-52. Bd. VI. M4 Badenian (Moravien, Wielicien, Kosovien). VEDA SAV, Bratislava.

PERYT D. (1997) - Calcareous nannoplankton stratigraphy of the Middle Miocene in the Gliwice area (Upper Silesia, Poland). Bull. Pol. Acad. Sc., Earth Sc., 45 (2-4): 119-131.

PERYT D. and GEDL P. (2010) - Paleoenvironmental changes preceding the Middle Miocene Badenian salinity crisis in the northern Polish Carpathian Foredeep Basin (Borków quarry) inferred from foraminifers and dinoflagellate cysts. Geol. Quart., 54 (4): 487-508.

PERYT T.M. (2006) - The beginning, development and termination of the Middle Miocene Badenian salinity crisis in Central Paratethys. Sedim. Geol., 188-189: 379-396.

PERYT T.M., HAŁAS S., KAROLI S. and PERYT D. (1997) - Isotopic record of environmental changes during deposition of Badenian (Middle Miocene) gypsum at Kobeřice near Opava (Czech Republic) (in Polish with English summary). Prz. Geol., 45 (8): 807-811.

RÖGL F. (1998) - Palaeogeographic considerations for Mediterranean and Paratethys seaways (Oligocene to Miocene). Ann. Naturhist. Mus. Wien, 99A: 279-310.

RÖGL F. and STEININGER F.F. (1984) - Neogene Paratethys, Mediterranean and Indo-Pacific seaways. In: Fossils and Climate (ed. P. Branchley): 171-200. Wiley.

SADOWSKA A. (1997) - Miocene palynology in the Gliwice region (Upper Silesia, Poland). Bull. Pol. Acad. Sc., Earth Sc., 45 (2-4): 203-210.

SZCZECHURA J. (1982) - Middle Miocene foraminiferal biochronology and ecology of SE Poland. Acta Palaeont. Pol., 27 (1-4): 3-44.

SZCZECHURA J. (1997) - Bolboforms (Protophyta, incertae sedis) from the Middle Miocene of the Upper Silesia (Carpathian Foredeep, southwestern Poland). Bull. Pol. Acad. Sc., Earth Sc., 45 (2-4): 133-144.

WITKOWSKI A. and GONERA M. (1997) - Miocene diatom flora from Central Paratethys (Carpathian Foredeep, Upper Silesia) - preliminary results. Bull. Pol. Acad. Sc., Earth Sc., 45 (2-4): 181-190. 